\title{
Partnering for development: German-South African perspectives on religion and state cooperation
}

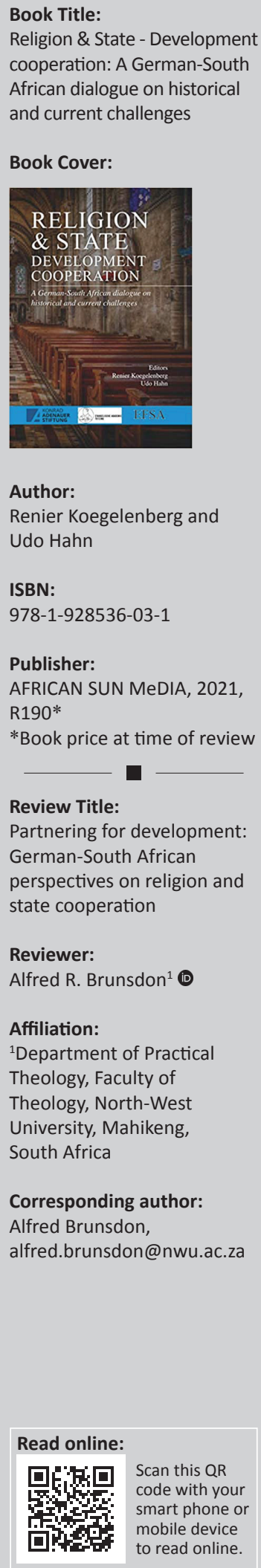

Religion \& State - Development cooperation: A German-South African dialogue on historical and current challenges is a collective work, that draws on presentations made at different events in the ongoing dialogue between Germany and South Africa, that focus on the dynamics of religion and state development cooperation. Readers of this publication are indebted to editors Renier Koegelenberg (Executive director of the Ecumenical Foundation of Southern Africa [EFSA]) and Udo Hahn (Director of the Evangelische Akademie Tutzing [EAT] Germany) who made the significant contributions of 21 authoritative voices on the topic, available to a wider reader public.

Mindful of the large number of contributions, the book is sub-divided into two sections. The focus of Section 1 is on 'Challenges posed by global changes and pandemics', and the focus of Section 2 is on 'Religion and state: Between cooption and cooperation'. These two sections are thoughtfully presented between the contributions of Horst Köhler ('Africa and Europe: A chance for a new start?') and Sithembele Sipuka ('Human dignity and human development - our rationale for cooperation') which organically serve as introduction and conclusion to the collection.

The first section, 'Challenges posed by global changes and pandemics', marks the work as both timeous and socially responsive. Six authors contributed to this section on topics ranging from COVID-19 to HIV. The first theme, 'We need to rethink (just about) everything', by Mcbebisi Jonas, sets a fitting framework for the rest of the chapters in this section which deals with responses to pandemics and the changes it imposes on global citizens, by contemplating the need for rethinking our stances on the globe (p. 22), government (p. 24), technology (p. 25) and a host of other pivotal aspects of public life. Against this background, authors like Zwelini Mkhize, Thabo Makgoba and others offer their insights regarding major pandemics such as COVID-19 and HIV.

Section 2 engages the relationship between religion and state under the subheading, 'Between cooption and cooperation', to pay recognition to the fine balance needed to manage this intricate social dynamic. In terms of volume, section two outweighs the first section by far with contributions by eighteen authors. The section is further sub-divided in 'Church perspectives', 'Political and government perspectives', 'UN Agenda 2030 for sustainable devlopment: The role and responsibility of churches and religious communities', 'Responsibility in church and state: Experiences between loyalty, willingness to compromise and conflict' and 'Opportunities and limitations for cooperation from the perspective of national and international church development organisations'. Contributors to this section also include significant voices from academia, state and church leadership from both South Africa and Germany.

The editors of this collective work have done well in organising the book into a meaningful unity in spite of the fact that it draws on papers presented at different occasions. Due to the high standard of the chapters, each can be read as an independent contribution to the over-arching theme. The main impression the book makes, is the representative voice it provides from major stakeholders in this particular debate.

The book should resonate well with church and political leaders, as well as with theologians with a keen interest in sustainable development and public theology. It is a thought-provoking and welcome book in a world that is currently disrupted, providing meaningful suggestions to two of the most influential societal role-players, namely church and state.

How to cite this article: Brunsdon, A.R., 2021, 'Partnering for development: German-South African perspectives on religion and state cooperation', In die Skriflig 55(1), a2768. https://doi.org/10.4102/ids.v55i1.2768

Copyright: ( 2021 . The Authors. Licensee: AOSIS. This work is licensed under the Creative Commons Attribution License. 